Ю. А. Лазуткіна

\title{
ФОРМИ ТА МЕТОДИ ФАХОВОЇ ПІДГОТОВКИ СТУДЕНТІВ У ПРОЦЕСІ САМОСТІЙНОЇ РОБОТИ НА УРОКАХ З АНГЛІЙСЬКОї МОВИ
}

Лазуткіна Ю. А. Форми та методи фахової підготовки студентів у процесі самостійної роботи на уроках з англійської мови.

У статті розглядаються методи самостійної роботи студентів при вивчені іноземної мови, їі види та форми. Проаналізовано підходи до організації самостійної діяльності студентів у сучасних умовах. Розкрито ключові складники впливу на покращення ефективності професійної підготовки майбутніх фахівців.

Ключові слова: самостійна робота студентів, форми та методи навчання, ефективність, мовна підготовка фахівця, професійна освіта.

Лазуткина Ю. А. Формы и методы профессиональной подготовки студентов в процессе самостоятельной работы на уроках английского языка.

В статье рассматриваются методы самостоятельной работы студентов при изучении иностранного языка, ее виды и формы. Анализируются пути организации самостоятельной работы студента в современных условиях. Раскрываются ключевые составляющие влияния на улучшение эффективности профессиональной подготовки будущих специалистов.

Ключевые слова: самостоятельная робота студентов, формы и методы обучения, эффективность, языковая подготовка специалиста, профессиональное образование.

Lazutkina Yu. A. Forms and methods of student's professional training in the process of self-guided work at English lessons

The article describes the self-guided (individual) work methods of students in foreign language learning, its types and forms. The problems of self-guided work have been analyzed. The key components of influence on improvement of efficiency in professional training of graduates have been discovered.

Key words: students self-guided work, methods and forms of education, effectiveness, higher education.

У сучасних умовах реформування освітньої системи в Україні значне місце належить пошуку ефективних методів і засобів навчання, розробці методичних систем, технологій викладання, підвищенню дієвості навчання загалом, розвитку у студентів самостійності, що виявляється в їхній здатності до самоорганізації, самовиховання та самоосвіти. Сучасна освітня програма ВНЗ пропонує велику кількість годин для самостійної роботи студента. Такий підхід зумовлений тим, 
що самостійна робота на уроках англійської мови сприяє розвитку й активізації творчих здібностей студента, розширює їхній полікультурний світогляд, розвиває мислення. Практична мета навчання англійської мови у ВНЗ полягає в тому, щоб формувати й розвивати вміння і навички усного мовлення, навчати читати не тільки адаптовану, але й оригінальну літературу, розуміти носіїв англійської мови. Для кращого засвоєння знань та оволодіння певними вміннями й навичками у процесі вивчення англійської мови необхідно активізувати пізнавальну й розумову діяльність учнів. Одним із важливих засобів такої активізації $є$ правильно організована самостійна робота як на уроках англійської мови, так і в позаурочний час. Самостійна робота виступає як завершення інших видів навчального процесу i може здійснюватися в межах семінарських, практичних занять, а також консультацій. При цьому виступає як метод навчання [2, с. 49].

На сучасному етапі розвитку методики навчання іноземних мов науковці, методисти, викладачі активно розв'язують питання побудови системи самостійної роботи з англійської мови студентів ВНЗ на основі синтезу новітніх педагогічних технологій і найефективніших методів навчання конкретної іноземної мови. Важливого значення набуває впровадження якісно нових видів, форм i методів організації самостійної роботи на уроках, зокрема, англійської мови, зорієнтованих на професійну діяльність студентів як майбутніх фахівців. Самостійна робота як метод навчання передбачає формування важливих загальнонавчальних умінь (аналізувати, планувати, порівнювати, контролювати), певних рефлексивних якостей, що врешті-решт забезпечує розвиток самостійності якості особистості, формує суб'єкта навчальної діяльності [1, с. 65].

Незважаючи на широкий і багатоплановий характер досліджень, присвячених організації самостійної роботи студентів, багато питань цієї складної проблеми залишаються поки що не вичерпаними i потребують подальшого дослідження, а саме нові форми та методи самостійної роботи студента як майбутнього фахівця. Актуальність проблеми зумовлюється тим, що з роками помітно зріс інтерес до самостійної роботи студентів, збільшилася роль самостійних робіт у навчальному процесі. Самостийна робота відіграє провідну роль на парі та сприймається як засіб навчання. Актуальним для нового методу навчання $є$ створення умов для формування критичного ๑ Ю. А. Лазуткіна, 2015. 
мислення, рефлексії, психології досягнень і навичок саморозвитку.

Мета статті полягає в тому, щоб дослідити форми та методи фахової підготовки студентів у процесі самостійної роботи на уроках 3 англійської мови. Для досягнення мети розв'язували такі завдання, як-от: з'ясувати шляхи та методи оволодіння студентами навичками самостійної роботи у процесі вивчення іноземної мови, належну обізнаність у читанні спеціальної літератури за фахом і вміння швидко орієнтуватися; забезпечити індивідуалізацію читання у студентів різного рівня розвитку багатогранної, довідкової, науково-пізнавальної літератури; розглянути можливості використання домашнього читання як важливого засобу формування комунікативної компетенції; виявити особливості процесу організації роботи над текстами 3 домашнього читання на уроках англійської мови; проаналізувати застосування різноманітних методів і форм проведення цієї роботи.

У психолого-педагогічній літературі переконливо доведено, що правильно організована самостійна робота студента сприяє значному підвищенню ефективності навчання, активізації навчальнопізнавальної діяльності (П. Голант, М. Данилов, Н. Дайрі, Б. Ссипов, Р. Лемберг, І. Малкін, Р. Мікельсон, І. Огородніков, Т. Панфілов, М. Скаткін, Р. Срода, А. Усова та ін.). Різні аспекти цієї проблеми висвітлені в ряді дисертацій (Л. Аристова, I. Варава, I. Дорно, В. Каленик, М. Ковалевська, В. Кривошеєв, Н. Нікольська, Л. Піменова, Г. Полещук, М. Пархунова, К. Соколова та ін.)

Загальнодидактичні, психологічні й методичні аспекти планування й організації самостійної роботи учнів розглядаються в роботах вітчизняних та зарубіжних науковці, зокрема С. Архангельського, Ю. Бабанського, Т. Балицької, І. Бендер, В. Буряк, Л. Вяткина, М. Гарунова, В. Графа, О. Данилова, Б. Ссипова, І. Ільясова, В. Козакова, М. Князян, В. Луценко, І. Малкіна, П. Підкасистого, О. Савченко, М. Скаткина, М. Солдатенко, В. Ужик, А. Усової, І. Хом’юк, Т. Шамової, Н. Шишкіної, В. Якуніна та інших. Чимало досліджень цієї проблеми проведено і в царині методики навчання іноземних мов (Г. Бурденюк, С. Заскалєта, Л. Іванова, Н. Коряковцева, Н. Магазова, Л. Онучак, Ф. Рабінович, Г. Рогова, І. Качан, Л. Грачова, Н. Фадєєва, І. Зимня, Л. Малишевська, В. Редько та ін.).

Одним із найдоступніших i перевірених практикою методів підвищення ефективності викладання іноземної мови, активізації 
студентів на занятті є організація самостійної навчальної роботи. Ефективність виконання самостійної роботи у процесі навчання багато в чому залежить від умов iї організації, форми та характеру завдань, логіки викладу знань, якості досягнутих студентами результатів під час виконання цієї роботи і т. ін. Плануючи урок, викладач обов'язково має визначити завдання для самостійного опрацювання студентами, зважаючи на професійне становлення майбутнього фахівця, а також вибрати відповідну форму контролю. Це може бути самоконтроль 3 опорою на ключі, алгоритми, зразки, схеми тощо або ж контроль $з$ боку викладача. Систематичні заходи, спрямовані на організацію самостійної роботи студента, будуть формувати не лише пізнавальну діяльність, а й самостійність як рису характеру. Якщо при цьому викладач ставить завдання сформувати навички самостійної роботи студента, то йому потрібно добре все продумати, а саме визначити:

- мету, час і характер самостійної роботи, а так само моменти, на які треба звернути увагу;

- спосіб повторення того мінімуму фактичних знань і умінь, без яких неможливе успішне виконання самостійної роботи.

Важливо також формувати у студента навички самостійної роботи вдома, давати чіткі настанови щодо виконання домашніх завдань. Наприклад, з викладацького досвіду пропоную такі інструкції в момент подачі домашнього завдання:

- читаючи текст, знайдіть речення, які є відповіддю на запитання, що стоять перед текстом;

- знайдіть речення, які можуть бути пунктами плану;

- визначте, яку інформацію (які речення) можна пропустити, не порушивши зміст тексту;

- розбийте текст на більш-менш самостійні уривки.

У сучасній педагогічний практиці серед найефективніших методів самостійної роботи студентів, що сприяють інтенсифікації та індивідуалізації навчального процесу, слід виокремити: проблемнопошукові методи; метод проектного навчання; методи колективної розумової діяльності; метод застосування новітніх інформаційнокомунікативних технологій у навчанні [4].

Необхідність пошуку нових підходів щодо організації самостійної діяльності студентів у сучасних умовах зумовлено тим, що саме в період навчання в ВНЗ у майбутніх фахівців закладаються основи ๑ Ю. А. Лазуткіна, 2015. 
професіоналізму, тому форми та методи самостійної роботи повинні відповідати таким вимогам:

1. Мотивація виконання необхідних завдань загалом.

2. Рекомендації щодо виконання роботи (подати зразок виконання).

3. Урахування творчих здібностей студента.

4. Розробка індивідуальних підходів щодо організації СР.

5. Чітке визначення завдань.

6. Зворотний зв'язок зі студентами у процесі виконання СР.

Будь-яка самостійна робота на певному рівні самостійності має конкретну мету, яку студент повинен усвідомити та прийняти. Викладач перед тим, як сформулювати завдання, інструктує студентів щодо порядку і прийомів виконання роботи. Далі студент продумує послідовність дій та оцінює умови досягнення мети. При цьому самостійна робота повинна відповідати навчальним можливостям студента, а ступінь складності задовольняти принцип поступового переходу 3 одного рівня самостійності на інший. У навчальному процесі повинні використовуватися результати, висновки самостійної, зокрема й домашньої роботи. Самостійну роботу організовують так, щоб виробити навички i звичку до працездатності майбутнього фахівця, сформувати готовність до саморозвитку в науковій професійній діяльності.

Необхідно зазначити умови, від яких залежить успіх самостійної навчальної роботи, а саме:

- поєднання різноманітних видів самостійних робіт та керівництво самим процесом;

- зміст роботи і форма ії виконання (зацікавленість студента, бажання довести роботу до кінця);

- індивідуальний підхід до організації самостійної роботи;

- надання детальних рекомендацій;

- підтримання зворотного зв'язку з викладачем.

Особливої уваги потребує така форма самостійної діяльності, як читання спеціальної літератури за фахом. Безсумнівно, що інтенсивне читання дає змогу опанувати велику кількість мовних комбінацій, граматичних структур та лексичних словосполук за значно коротший проміжок часу. Систематичне та планомірне домашнє читання $\epsilon$ важливим джерелом i засобом поповнення лексичного запасу та розвитку навичок усного мовлення студентів. Необхідно, щоб ці 
тексти грунтувалися на вивченому лексичному й граматичному матеріалі. Наявна думка, що домашнє читання 3 англійської мови повинно бути вправою лише в читанні i що його не треба ускладнювати іншими видами мовної діяльності (обговорення прочитаного). Таке твердження викликає суперечності при розгляді доцільності використання домашнього читання. Тому ускладнення читання вправами та завданнями - необхідна умова, яка мотивує в подальшому мовленнєву діяльність при вивченні англійської мови. Окрім мовної та мовленнєвої компетенції, значну увагу приділяють формуванню компетенції читання та письма при роботі над текстами 3 домашнього читання англійської мови. Формування компетенції читання технологічно поділяють на традиційно визначені етапи: PreReading Activities, Reading Comprehension, Post-Reading Activities. Передтекстові завдання спрямовані на мотивування читача, розвиток його прогностичних навичок, підготовку до сприйняття тексту. Вони спираються на певні текстові «сигнали» (заголовок розділу, певні цитати з тексту, назви, події попередніх розділів), читачеві пропонуються кілька варіантів розвитку подій, пропонують студентам висловити своє бачення тієї чи тієї проблеми. Завдання на перевірку розуміння прочитаного мають на меті: стимулювати студентів до уважного читання тексту й перевірити розуміння змісту загалом і значення окремих текстових фрагментів зокрема.

Працюючи 3 періодичними виданнями іноземною мовою, варто більше уваги приділяти коротким пошуковим завданням: виписати фахову лексику, проаналізувати назви статей, скласти оголошення за зразком, скласти план статті, що зацікавила, проаналізувати рекламні слогани. Питання на перевірку уваги роблять акцент на певних деталях і формулюються так, щоб читачеві самому було цікаво знайти відповідь, за необхідності повторно звернутися до тексту [5].

Задля розвитку здібностей i творчості студентів необхідно індивідуалізувати самостійні завдання з читання літератури за фахом. Для цього виокремлюють або спеціально розробляють три варіанти завдань: перший (високий рівень складності) - вимагає творчого підходу й пізнавальної самостійності; другий (середній рівень складності) - передбачає розв'язання складних завдань, які містять вказівки чи підказки; третій (низький рівень складності) - передбачає виконання завдань переважно репродуктивного характеру. Ефективною () Ю. А. Лазуткіна, 2015. 
формою індивідуалізації самостійної роботи є підготовка завдань на картках. Самостійна робота 3 виконанням навчального завдання охоплює три етапи [3, с. 159]:

1. Підготовка студента до виконання завдання. Теоретичне, психологічне, організаційно-методичне й матеріально-технічне забезпечення самостійної роботи.

Внутрішнє сприйняття завдання починається 3 актуалізації мотиву, що спонукає студента до виконання поставленого завдання, відповідно, до організації своєї самостійної роботи.

Успіх підготовчого етапу залежить i від організаційного, методичного, матеріально-технічного забезпечення самостійної роботи студента (забезпеченість літературою, методичними рекомендаціями, наочними посібниками, інформаційно-комп'ютерною базою тощо).

2. Безпосереднє виконання навчального завдання.

3. Аналіз виконаного завдання $є$ завершальним етапом виконаної роботи. Самоконтроль призначений для самооцінки студентами якості засвоєння навчального матеріалу 3 конкретної дисципліни (розділу, теми). Задля цього в навчальних посібниках для кожної теми (розділу), а також у методичних розробках із практичних робіт передбачаються питання для самоконтролю. Більша ефективність самоконтролю забезпечується спеціальними програмами самоконтролю й самооцінки, які є складовими частинами електронних підручників та автоматизованих навчальних курсів.

Виховання у студентів навичок самостійної роботи з навчальним матеріалом, науковою та навчально-методичною літературою належить до першочергових завдань ВНЗ. Адже водночас вони виховуватимуть у собі організаційність, системність, діловитість, зосередженість, без чого не обійтися в майбутній професійній діяльності.

Отже, ураховуючи складний процес і специфіку навчання, не слід недооцінювати важливість проблеми оволодіння студентами методами та формами самостійного навчання. Неможливо здійснити якісну підготовку висококваліфікованого спеціаліста в сучасних умовах без залучення студентів до самостійної роботи. Самостійна робота тісно пов'язана 3 аудиторною, є важливим і дієвим джерелом розвитку й саморозвитку особистості студента. Її продуктивність залежить від ефективності й організації, де значна роль відводиться викладачеві, який має спланувати навчальний процес так, аби викликати зацікавленість 
студентів. Сучасна концепція вищої професійної освіти тісно пов'язує процес і результат навчання 3 рівнем організації самостійної роботи студентів, оскільки система вищої освіти покликана не тільки дати певну систему знань, але й сформувати професійні якості майбутніх фахівців. До подальших напрямів дослідження сучасних особливостей фахової підготовки спеціалістів зараховуємо перспективу пошуків форм і методів організації самостійної роботи студента для створення професійного середовища на основі комп'ютерних телекомунікацій.

\section{Література}

1. Бєлкін Є. Педагогічні основи організації самостійної роботи студентів у ВНЗ : [навчальний посібник] / Є. Белкін. - Одеса : Знання, 1989. - 165 с.

2. Буряк В. Керування самостійною роботою студентів / В. Буряк // Вища школа. 2001. - № 4-5. - C. 52.

3. Дичківська I. М. Інноваційні педагогічні технології / І. М. Дичківська. - К. : Академвидав, 2004. - $351 \mathrm{c}$.

4. Долженко О. В. Сучасні методи та технології навчання у технічному вузі : [підручник] / О. В. Долженко, В. Л. Шатуновський. - М. : Вища школа, 1990. - 315 с.

5. Єсіпов Б. П. Самостійна робота учнів на уроках : [навчальний посібник] / Б. П. Єсіпов. - М. : Навч. пед. гіз., 1980. - 112 с.

Стаття надійшла до редакиії 06.04.2015 p. 